\title{
Kelayakan dan Strategi Pengembangan Usaha pada Outlet Ayam Goreng Waralaba dan Mandiri
}

Feasibility and Business Development Strategy of Franchise and/or Independent Fried Chicken Outlet

\author{
Bambang Widuri ${ }^{1 *}$, Amiruddin Saleh ${ }^{2 \sharp}$ dan Nurheni Sri Palupi ${ }^{3 *}$
}

${ }^{1}$ PT Arutmin Indonesia

${ }^{2}$ Departemen Komunikasi dan Pengembangan Masyarakat, Fakultas Ekologi Manusia Institut Pertanian Bogor

${ }^{3}$ Departemen Ilmu dan Teknologi Pangan, Fakultas Teknologi Pertanian, Institut Pertanian Bogor \#Jl. Kamper, Kampus IPB Darmaga, Bogor 16680

\begin{abstract}
ABSTRAK
Kunci keberhasilan usaha kecil dan menengah terletak pada kepemilikan pengetahuan, keberanian dan kesungguhan dalam menjalankan usaha. Saat ini, untuk meminimalkan risiko yang mungkin timbul, banyak pengusaha kecil, terutama pengusaha pemula, menggunakan sistem waralaba (franchise) sebagai sarana dalam mengembangkan usaha. Kegagalan dalam berbisnis waralaba dapat ditelusuri melalui beberapa aspek, yaitu aspek keuangan, manajemen dan aspek pemasaran Tujuan penelitian ini: (1) mendeskripsikan kelayakan usaha ayam outlet ayam goreng waralaba dan mandiri, (2) mendeskripsikan persepsi konsumen terhadap produk ayam goreng waralaba dan mandiri, (3) menyusun strategi yang tepat untuk pengembangan usaha waralaba dan mandiri. Penelitian dilaksanakan di outlet waralaba Sabana dan Mandiri, Bogor. Pengambilan responden dilakukan dengan teknik purposive sampling dengan 124 responden. Teknik pengolahan data menggunakan analisis Net Present Value (NPV), Internal Rate of Return (IRR), Net Benefit Cost Ratio (Net B/C), Payback Period (PBP), Internal Factor Evaluation (IFE), External Factor Evaluation (EFE), Internal-External (IE), Strenghts, Weaknesses, Opportunities and Threats (SWOT) dan Quantitative Strategic Planning Matrix (QSPM). Berdasarkan analisis kelayakan usaha, outlet penjualan ayam goreng secara waralaba maupun mandiri layak untuk dilakukan. Sistem usaha waralaba mendapatkan tingkat pengembalian lebih tinggi dan lebih cepat mencapai titik impas daripada secara mandiri. Outlet waralaba lebih mendapatkan kepercayaan dari konsumen karena lebih praktis, harga lebih murah menyebabkan tingkat pengembalian modal lebih cepat. Alasan konsumen untuk membeli produk adalah harga, praktek, dan higiene. Berdasarkan hasil perhitungan matriks QSP ayam goreng waralaba, diperoleh strategi diterapkan adalah menjaga loyalitas konsumen, sementara usaha mandiri adalah meningkatkan mutu produk dan layanan.
\end{abstract}

Kata kunci: ayam goreng, kelayakan usaha, pengembangan usaha, waralaba

\begin{abstract}
The key to the success of small and medium enterprises located in the possession of knowledge, courage and sincerity in running the business. Currently, in order to minimize the risks that may arise, many small businesses, especially entrepreneurs, using the franchise system (franchise) as a means to develop their business. Failure in business franchise can be traced through several aspects, namely finance, management and marketing aspects. The purposes of the study are: (1) to describe the feasibility of fried chicken business with franchise and independent system, (2) to describe the perception of consumers towards the products of fried chicken business with franchise and independent system, (3) to develop appropriate strategies for developing franchise and/or independent system. The study was conducted at franchised/independent outlet located Bogor regency. Respondent has been collected by purposive sampling with 124 respondens. The experiment was conducted from February to March 2012.
\end{abstract}


Kind of data processing technique we used was Net Present Value (NPV), Internal Rate of Return (IRR), Net Benefit Cost Ratio (Net B / C), Payback Period (PBP), Internal Factor Evaluation (IFE), External Factor Evaluation (EFE), Internal-External (IE), Strength, Weaknesses, Opportunities and Threats (SWOT) and Quantitative Strategic Planning (QSP) analysis system. Based on feasibility analysis, both fried chicken business with franchise and independent systems are feasible to be implemented. Franchise system offers more opportunity to get higher and faster returns, as well as to reach PBP faster than independent system. Furthermore, fried chicken business with franchise system shall be easier to get the trust of consumers because that system is more practical and besides, that system also offers cheaper price which will drive someone to reach PBP and return on capital faster. The reason of consumer to buy product are price, practice, and higiene. Based on the results of the matrix QSP fried chicken franchise, earned the most interesting strategy to be applied is to maintain customer loyalty, while independent business is improving the quality of products and services.

Key words: business development, customer behaviours, feasibility, franchise, fried chicken

\section{PENDAHULUAN}

Pengembangan sektor usaha mikro, kecil dan menengah di Indonesia masih mengalami berbagai kendala mulai dari akses pasar sampai akses permodalan. Kendala ini sekaligus menjadikan tantangan bagi pengusaha kecil untuk berkembang. Kunci keberhasilan usaha kecil dan menengah terletak pada kepemilikan pengetahuan, keberanian dan kesungguhan dalam menjalankan usaha.

Di sisi lain, dengan semakin ketatnya persaingan usaha kecil, sangat diperlukan agar usaha ini tidak terdesak dengan usaha besar dan investor mancanegara (Wati, 2009). Untuk meminimalkan risiko yang mungkin timbul, banyak pengusaha kecil saat ini, terutama pengusaha pemula, menggunakan sistem waralaba (franchise) sebagai sarana dalam mengembangkan usaha. Untuk mengembangkan usaha mikro dan kecil memerlukan informasi yang menyeluruh (holistic) dan serba cakup atau integratif sebagai acuan referensi untuk melihat secara mendalam kondisi dan perilaku dari suatu sektor sehingga dapat ditentukan langkah kebijakan atau pembinaan yang akan diterapkan terhadap sektor tersebut (Zabidi, 2001).

Karamoy (2005) berpendapat bahwa bidang usaha potensial dan prospektif untuk dikembangkan secara waralaba di Indonesia adalah bidang usaha makanan yang meliputi restoran, café/sport bar, makanan siap saji (fast food), makanan bercirikan etnik (masakan padang, bakso, gadogado, dan lain-lain). Namun demikian, upayaupaya penataan usaha warala di Indonesia hendaknya berorientasi untuk memberikan dukungan penuh pada waralaba berbasis UMKM (Rivai, 2012).
Saat ini terdapat beberapa waralaba ayam goreng sebagai menu utama, dari yang berskala besar sampai kecil. Beberapa kelebihan bisnis waralaba bagi terwaralaba, yaitu memiliki keuntungan dari program penelitian dan pengembangan, jaminan territorial daerah bisnis, serta promosi yang dilakukan oleh pewaralaba. Pewaralaba sudah memiliki tim manajemen yang kuat, pewaralaba memiliki modal memadai untuk memulai dan mengembangkan program waralaba, identitas dagang yang khas, unit, berbeda dengan usaha sejenis lain dan dilindungi oleh hukum, quality control yang jelas di bidang administrasi, dan sebagainya. Selain itu, keuntungan franchising bagi franchisor adalah bisnisnya bisa berkembang dengan cepat di banyak lokasi secara bersamaan, meningkatnya keuntungan dengan memanfaatkan investasi dari franchisee (Astuti, 2005).

Kegagalan dalam berbisnis waralaba dapat ditelusuri melalui beberapa aspek, yaitu aspek keuangan, manajemen dan aspek pemasaran. Ketiga aspek tersebut saling berhubungan dan secara sederhana bahwa usaha yang sehat adalah yang menghasilkan keuntungan.

Dalam meningkatkan penjualan produk, ayam goreng bisnis waralaba ataupun produk ayam goreng mandiri, sangat tergantung dari selera konsumen. Untuk itu, perlu kiranya mengetahui kebutuhan dan harapan konsumen dan berupaya untuk memenuhi keinginan tersebut, sehingga konsumen merasa puas. Kepuasan atas pelayanan dapat menjadikan konsumen loyal sehingga mempunyai potensi sebagai iklan berjalan yang efektif dan efisien.

Tujuan kajian ini: (1) menganalisis kelayakan usaha outlet ayam goreng waralaba dan mandiri, (2) menganalisis persepsi konsumen terhadap produk ayam goreng, (3) menyusun strategi yang tepat untuk pengembangan usaha. 


\section{METODOLOGI}

Lokasi utama penelitian di outlet ayam goreng waralaba maupun mandiri, dimana pemilihan lokasi dilakukan secara purposive. Penelitian ini bersifat deskriptif kualitatif untuk mendeskripsikan kelayakan usaha, perilaku konsumen dan alternatif strategi ayam goreng waralaba dan mandiri. Penelitian dilakukan pada bulan Februari-Maret 2012.

Pengumpulan data dengan melakukan pengamatan (observasi) di lapangan, wawancara dan pengisian kuesioner oleh pengusaha ayam goreng waralaba dan mandiri, serta konsumennya. Kuesioner disusun dengan mengacu pada kuesioner yang dibuat oleh Aryanti (2010) dengan beberapa modifikasi. Data primer kuantitatif yang dibutuhkan dalam menganalisa kelayakan usaha antara lain aset, modal, omset penjualan, biaya, laba kotor dan laba bersih.

Penentuan responden menggunakan metode judgement sampling berdasarkan penilaian bahwa responden tersebut adalah orang yang tepat dan baik untuk dijadikan responden, karena merupakan faktor penentu dalam pengambilan keputusan di perusahaan. Jumlah responden yang diteliti sebanyak 120 orang yang masing masing terdiri atas: (a) responden untuk mendapatkan informasi tentang kelayakan dan pengembangan usaha, yaitu 2 responden pemilik outlet ayam goreng waralaba, 2 responden pemilik outlet ayam goreng mandiri, (b) responden untuk mengetahui perilaku atau preferensi konsumen diperoleh dari 60 responden konsumen outlet ayam goreng waralaba dan 60 responden konsumen outlet ayam goreng mandiri. Konsumen yang dijadikan responden, yaitu konsumen yang sudah pernah mengkonsumsi produk pada masing-masing usaha ayam goreng tersebut.

Pengolahan data yang digunakan untuk menjawab tujuan dalam penelitian ini dapat dilihat pada Tabel 1. Data yang diperoleh, baik data primer maupun sekunder dilakukan pengolahan, agar dapat dibaca dan dianalisis lebih lanjut, sehingga dapat diinterpretasikan.

Data yang telah diperoleh dalam kajian ini, baik primer maupun sekunder diolah secara deskriptif dalam bentuk frekuensi, persentase, rataan skor dan tabulasi silang. Data yang telah diolah, kemudian dianalisis dengan (1) analisis kelayakan yang meliputi NPV, IRR, Net B/C dan Payback Period, dimana batasan analisisnya pada aspek finansial, teknis/teknologi, manajemen operasional; (2) analisis SWOT dan (3) QSPM.

\section{HASIL DAN PEMBAHASAN}

\section{Usaha Terwaralaba}

\section{Outlet Sabana 1}

Outlet Sabana 1 beroperasi mulai pukul 11.00 WIB sampai pukul 21.00 WIB, libur pada satu pekan satu hari dan pada hari raya Idul Fitri/Idul Adha. Untuk menarik pembeli, pemasaran dilakukan melalui penyebaran brosur ke rumah-rumah di dalam kompleks. Selain penjualan di outlet, terwaralaba juga melayani penjualan secara pesanan, tetapi penjualan dengan cara semacam ini belum banyak menarik pembeli. Terwaralaba tidak memberikan fee atau komisi kepada pewaralaba, tetapi diwajibkan untuk membeli daging ayam segar beserta tepung bumbunya kepada pewaralaba atau agen yang ditunjuk.

Tabel 1. Metode analisis data berdasarkan tujuan penelitian

\begin{tabular}{|c|c|c|c|c|}
\hline \multirow{2}{*}{ No } & \multirow{2}{*}{ Tujuan Penelitian } & \multicolumn{2}{|c|}{ Data } & \multirow{2}{*}{$\begin{array}{l}\text { Metode } \\
\text { Analisis }\end{array}$} \\
\hline & & Jenis & Sumber & \\
\hline 1. & $\begin{array}{l}\text { Mendeskripsikan kelayakan } \\
\text { usaha outlet ayam goreng } \\
\text { waralaba dan mandiri. }\end{array}$ & $\begin{array}{l}\text { Aset, Modal, Omset Penjualan, } \\
\text { Biaya, Laba Kotor, Laba Bersih } \\
\text { dan Operasional tahun 2009- } \\
2011\end{array}$ & $\begin{array}{l}\text { Survei, pembu- } \\
\text { kuan usaha dan } \\
\text { kuesioner }\end{array}$ & $\begin{array}{l}\text { Deskriptif, NPV, } \\
\text { IRR, Net B/C dan } \\
\text { Payback Period }\end{array}$ \\
\hline 2. & $\begin{array}{l}\text { Mendeskripsikan persepsi } \\
\text { konsumen terhadap produk } \\
\text { ayam goreng waralaba dan } \\
\text { mandiri }\end{array}$ & $\begin{array}{l}\text { Proses keputusan pembelian } \\
\text { terhadap produk ayam goreng }\end{array}$ & Survei, kuesioner & Deksriptif \\
\hline 3. & $\begin{array}{l}\text { Menyusun strategi yang tepat } \\
\text { untuk pengembangan usaha } \\
\text { waralaba dan mandiri }\end{array}$ & $\begin{array}{l}\text { Identifikasi faktor internal dan } \\
\text { eksternal perusahaan, pem- } \\
\text { bobotan, rating dan skor } \\
\text { Tahap pencocokan } \\
\text { Rumusan strategi }\end{array}$ & $\begin{array}{l}\text { Kuesioner, Faktor } \\
\text { lingkungan (faktor } \\
\text { internal dan eks- } \\
\text { ternal perusahaan) }\end{array}$ & $\begin{array}{l}\text { IFE, EFE, IE, } \\
\text { SWOT dan QSPM }\end{array}$ \\
\hline
\end{tabular}


Ayam goreng terwaralaba Sabana 1 memiliki struktur organisasi yang bersifat sederhana, terdiri dari pemilik dan karyawan. Pemilik bertugas memimpin, mengawasi dan bertanggung jawab penuh terhadap seluruh kegiatan outlet miliknya. Mencatat pemasukan dan pengeluaran uang setiap hari. Karyawan bertugas mengambil bahan mentah di distributor, berbelanja minyak goreng dan peralatan lain yang diperlukan, menjaga outlet, menyiapkan pesanan pembeli, serta menjaga kebersihan outlet. Selain memimpin jalannya operasional outlet, pemilik juga berfungsi sebagai pengganti jika karyawan tidak masuk.

\section{Outlet Sabana 2}

Outlet ayamg goreng terwaralaba Sabana 2 didirikan pada tahun 2009. Menu utama yang ditawarkan adalah berupa paha, dada dan sayap ayam goreng. Outlet Sabana 2 beroperasi mulai pukul 11.00-20.00 WIB. Ayam goreng Sabana 2 ini juga memiliki struktur organisasi sederhana, yang terdiri dari pemilik dan karyawan. Pemilik bertugas memimpin, mengawasi, dan bertanggung jawab penuh terhadap seluruh kegiatan outlet miliknya. Outlet Sabana 2 memiliki dua orang karyawan. Karyawan pertama bertugas mencatat pemasukan dan pengeluaran uang, mengambil bahan mentah di agen, berbelanja minyak goreng dan peralatan lain yang diperlukan, menggantikan menjaga outlet jika karyawan kedua tidak masuk kerja. Karyawan kedua bertugas melayani pembeli maupun menjaga kebersihan outlet.

\section{Outlet Asoka}

Ayam goreng Asoka memiliki struktur organisasi sederhana, terdiri dari pemilik dan karyawan. Pemilik bertugas memimpin, mengawasi, dan bertanggung jawab penuh terhadap seluruh kegiatan outlet miliknya. Mencatat pemasukan dan pengeluaran uang setiap hari, berbelanja, mempersiapkan perlengkapan. Pemilik bertugas berbelanja daging ayam, menyiapkan bumbu dan mengantarkannya ke outlet. Karyawan betugas berbelanja minyak goreng, gas, menjaga outlet, menyiapkan pesanan pembeli, dan menjaga kebersihan outlet. Selain memimpin jalannya operasional outlet, pemilik juga berfungsi sebagai pengganti, jika karyawan tidak masuk, melakukan sebagian tugasnya.

\section{Outlet Crunchys Fried Chicken}

Ayam goreng Crunchys Fried Chicken memiliki struktur organisasi sederhana, yang terdiri dari pemilik dan karyawan. Pemilik bertugas memimpin, mengawasi dan bertanggung jawab penuh terhadap seluruh kegiatan outlet miliknya. Karyawan pertama mencatat pemasukan dan pengeluaran uang setiap hari, berbelanja, mempersiapkan perlengkapan, berbelanja bahan baku dan menyiapkan bumbu, serta mengantarkannya ke outlet. Karyawan kedua bertugas melayani pembeli dan menjaga kebersihan outlet.

\section{Aspek keuangan}

\section{Kelayakan Usaha}

Kriteria yang digunakan dalam perhitungan meliputi NPV, Net B/C, IRR, dan PBP. Tingkat diskonto yang digunakan $5 \%$ per tahun merupakan tingkat suku bunga deposito Bank Mandiri periode Maret 2012. Analisis kelayakan finansial yang dilakukan adalah aspek finansial kelayakan usaha.

Pembelian peralatan investasi dilaksanakan pada tahun ke 0, yaitu tahun 2010. Perhitungan laba rugi dan cashflow merupakan data yang dimulai di tahun 2011-2014, dan dengan asumsi sampai dengan tahun keempat umur proyek besar inflow dibuat rataan mulai tahun 2009- 2011. Hasil rataan dianggap sampai dengan tahun 2014.

\section{Nilai Penjualan Total}

Nilai penjualan total outlet waralaba berasal dari data penjualan keseluruhan produk Sabana 1 dan 2. Total penjualan pada tahun pertama sama dengan keadaan nyata. Untuk tahun kedua hingga keempat pada setiap tahunnya diasumsikan konstan. Pada tahun ke nol perusahaan melakukan kegiatan investasi, sehingga pada tahun pertama perusahaan baru dapat melakukan kegiatan usahanya. Data Penjualan rataan ayam goreng waralaba dapat dilihat pada Tabel 2 dan 3.

\section{Nilai Sisa}

Nilai sisa adalah nilai barang atau peralatan yang tidak habis selama umur penghitungan dan dinilai masih memiliki umur ekonomis karena belum terpakai seluruhnya. Nilai sisa dihitung ditahun keempat, dan dimasukkan ke dalam komponen inflow. Pada usaha ayam goreng waralaba dan mandiri nilai sisa yang diakui adalah 1 juta rupiah setelah pemakaian selama lima tahun. 
Tabel 2. Data penjualan rataan outlet ayam goreng waralaba dari tahun 2010-2011

\begin{tabular}{clcccc}
\hline No. & \multicolumn{1}{c}{ Menu } & Satuan & $\begin{array}{c}\text { Rataan harga } \\
\text { produk (Rp) }\end{array}$ & $\begin{array}{c}\text { Total penjualan } \\
\text { rataan per hari (Rp) }\end{array}$ & $\begin{array}{c}\text { Total penjualan rataan } \\
\text { per bulan (Rp) }\end{array}$ \\
\hline 1. & Paha atas dan dada & Potong & 6.500 & 292.500 & 8.775 .000 \\
2. & Sayap dan paha bawah & Potong & 5.000 & 210.000 & 6.300 .000 \\
& & & $\mathbf{5 0 2 . 0 0 0}$ & $\mathbf{1 5 . 0 7 5 . 0 0 0}$ \\
\hline
\end{tabular}

Tabel 3. Data penjualan rataan outlet ayam goreng mandiri dari tahun 2010-2011

\begin{tabular}{clcccc}
\hline No & \multicolumn{1}{c}{ Menu } & Satuan & $\begin{array}{c}\text { Rataan harga } \\
\text { produk (Rp) }\end{array}$ & $\begin{array}{c}\text { Total Penjualan } \\
\text { rataan per hari (Rp) }\end{array}$ & $\begin{array}{c}\text { Total Penjualan } \\
\text { rataan per bulan (Rp) }\end{array}$ \\
\hline 1. & Paha atas dan dada & Potong & 7.000 & 105.000 & 3.178 .000 \\
2. & Sayap dan paha bawah & Potong & 5.000 & 140.000 & 4.290 .000 \\
& & & $\mathbf{2 4 5 . 0 0 0}$ & $\mathbf{7 . 4 6 8 . 0 0 0}$ \\
\hline
\end{tabular}

\section{Arus Pengeluaran}

Arus pengeluaran (outflow) dalam usaha ayam goreng waralaba dan mandiri terdiri dari biaya investasi dan biaya operasional perusahaan. Struktur pembiayaan pada usaha ayam goreng ini terdiri atas biaya investasi, biaya reinvestasi, biaya operasional, dan biaya penyusutan.

\section{a. Biaya Investasi}

Ayam goreng waralaba menginvestasikan Rp20 juta untuk pertama keikutsertaan pada waralaba sampai outlet tersebut masih buka. Ayam goreng mandiri rataan mengeluarkan dana Rp9,25 juta untuk investasi pertama.

\section{b. Biaya Reinvestasi}

Biaya reinvestasi dikeluarkan untuk aset yang memiliki umur ekonomis selama dua dan tiga tahun, karena umur ekonomis kurang dari umur proyek, yaitu lima tahun. Pada saat pembelian peralatan investasi dilakukan tahun 2010 akhir, data yang dimasukan pada perhitungan laba rugi dan cashflow merupakan data yang dimulai di tahun 2010, dengan asumsi sampai dengan tahun keempat umur proyek besar inflow dan outflow disamakan dengan data tahun 2011. Pada tahun ke nol yang dimulai pada tahun 2010 merupakan tahun awal dimulai investasi dan persiapan komponen peralatan investasi.

\section{c. Biaya Operasional}

Besarnya biaya operasional dapat dilihat pada Tabel 4 yang dikeluarkan pada tahun pertama penelitian, yaitu tahun 2011, di tahun kedua sampai keempat diasumsikan konstan.

Besar biaya operasional rataan per bulan yang dikeluarkan ayam goreng sabana pada tahun 2011 terdiri dari biaya variabel dan biaya tetap Rp15,065 juta, sedangkan mandiri Rp6,188 juta.

\section{d. Biaya Penyusutan}

Perhitungan nilai penyusutan aset per tahun sesuai dengan perkiraan umur ekonomis. Dalam penelitian ini digunakan metode garis lurus, sehingga penyusutan semua aset perusahaan diasumsikan sama untuk setiap tahunnya. Pada nilai penyusutan per tahunnya diperoleh dari total harga investasi dikurangi nilai sisa dibagi umur ekonomis, dan memiliki total hasil nilai penyusutan adalah 3,5 juta rupiah untuk ayam goreng waralaba dan 1,65 juta rupiah untuk ayam goreng mandiri.

Tabel 4. Biaya operasional rata-rata usaha ayam goreng waralaba dan mandiri setiap bulan selama Tahun 2011

\begin{tabular}{llrr}
\hline No. & Biaya operasional & $\begin{array}{r}\text { Waralaba } \\
\text { Rp })\end{array}$ & \multicolumn{1}{c}{$\begin{array}{c}\text { Mandiri } \\
(\mathrm{Rp})\end{array}$} \\
\hline A. & Biaya peubah & & \\
1. & Bahan baku utama & 11.369 .500 & 4.199 .000 \\
2. & Tepung & 1.032 .000 & 391.000 \\
3. & Minyak goreng & 327.500 & 133.000 \\
4. & Gas & 271.000 & 110.000 \\
5. & Saos/sambal & 172.000 & 69.500 \\
& Jumlah & 13.172 .000 & 4.902 .500 \\
\hline B. & Biaya Tetap & & \\
1. & Gaji karyawan & 1.275 .000 & 850.000 \\
2. & Sewa tempat & 375.000 & 350.000 \\
3. & THR & 200.000 & 50.000 \\
4. & Lain- lain & 42.500 & 35.000 \\
& Jumlah & 1.892 .500 & 1.285 .000 \\
\hline & Total biaya operasional & $\mathbf{1 5 . 0 6 4 . 5 0 0}$ & $\mathbf{6 . 1 8 7 . 5 0 0}$ \\
\hline
\end{tabular}

\section{Analisis Kriteria Kelayakan Finansial}

Analisis kelayakan finansial yang digunakan dalam penelitian ini adalah NPV, Net B/C, IRR dan PBP. Tingkat diskonto yang digunakan pada periode Maret 2012 sebesar 5\% per tahun. Perhitungan kelayakan ini menggunakan manfaat 
bersih (net benefit) yang diperoleh dari selisih antara biaya dan manfaat setiap tahunnya. Berdasarkan kriteria kelayakan finansial diperoleh nilai NPV ayam goreng waralaba Rp73,19 juta (positif) dan ayam goreng mandiri Rp3,70 juta (positif) atau lebih besar dari nol. Hal ini berarti bahwa usaha ayam goreng waralaba dan mandiri layak untuk dilaksanakan.

Net B/C yang dihasilkan adalah 4,66 untuk waralaba dan 1,57 untuk mandiri. Nilai tersebut menunjukkan setiap pengeluaran biaya Rp1 akan menghasilkan manfaat 4,66 kali pada waralaba atau 1,57 kali pada mandiri dari biaya yang dikeluarkan. Nilai Net B/C lebih besar daripada nol menunjukkan bahwa usaha ini layak untuk dilaksanakan.

Nilai IRR yang diperoleh $21,30 \%$ untuk waralaba dan 18,14 untuk mandiri dan IRR > 5\%, artinya proyek yang dilakukan oleh perusahaan memiliki tingkat pengembalian proyek terhadap investasi yang dikeluarkan 21,30 dan 18,14\%. Hasil analisis tingkat pengembalian investasi (PBP), memperlihatkan bahwa untuk waralaba diperlukan waktu selama 1,9 tahun dan 24 hari untuk waralaba dan 3,8 tahun dan 4 hari untuk mandiri.

Hal ini menunjukkan bahwa usaha outlet ayam goreng dapat mengembalikan modal sebelum umur lima tahun, sehingga usaha yang dilakukan masuk ke dalam kriteria layak untuk dilaksanakan. Dari keempat kriteria kelayakan, yaitu NPV, IRR, Net B/C, dan PBP menunjukkan bahwa usaha ayam goreng, baik waralaba maupun mandiri layak untuk dilakukan dan waralaba memberikan tingkat pengembalian hasil lebih cepat daripada mandiri.

\section{Aspek Teknis/Teknologi}

Outlet Waralaba dan Mandiri harus mengeluarkan ide-ide baru dalam mengikuti perkembangan teknologi pangan, khususnya yang berkaitan dengan pengelolaan produk, pemprosesan dan pelayanan yang baik. Kemajuan teknologi dalam perusahaan dapat menciptakan keunggulan komparatif baru yang lebih baik dari keunggulan saat ini. Hal ini didukung dengan pengetahuan mendalam mengenai penggunaan teknologi yang dipakai. Perkembangan komunikasi yang telah dilakukan adalah penggunaan telepon dan layanan pesan singkat (short message). Namun sayang, pengusaha outlet mandiri belum mencantumkan nomor telepon yang bisa dihubungi pada outletnya.
Perkembangan teknologi lainnya yang telah dilakukan outlet waralaba dan mandiri dalam hal keuangan adalah menggunakan komputer untuk mencatat dan menghitung aliran kas masuk maupun ke luar. Pemanfaatan teknologi oleh outlet mandiri dalam produksi antara lain dengan menggunakan deep fryer atau kompor yang sudah diatur dengan suhu tertentu dan akan mati secara otomatis jika suhu terlalu panas. Diharapkan dengan adanya beberapa alat tersebut dapat mempermudah dan mempercepat proses produksi.

\section{Manajemen Operasional}

Di outlet ayam goreng waralaba, satu ekor ayam mentah menjadi sembilan potong daging yang telah dicampur bumbu dengan standar mutu dan harga yang telah ditentukan. Bahan baku tersebut diambil setiap hari di distributor. Rataan kebutuhan ayam mentah setiap outlet 1520 ekor setiap hari. Sebagian dibawa ke outlet untuk langsung dilakukan peng-gorengan. Bahan baku lain yang harus dipersiap-kan adalah minyak goreng dan gas, sedangkan perlengkapan tambahan seperti sterofoam, kantong plastik harus belanja sendiri di pasar.

Outlet mandiri membeli bahan baku langsung dari pasar tradisional atau diantar oleh pemasok daging ayam. Satu ekor ayam mentah menjadi 12-15 potong daging, dilakukan pencampuran dengan adonan tepung yang sudah diberikan bumbu khusus. Sistem waralaba maupun mandiri menggunakan prinsip pemakaian bahan baku pola first in first out (FIFO) sesuai tanggal pembelian bahan baku dari distributor/ pasar tradisional, sehingga diharapkan tidak ada bahan baku yang kadaluwarsa.

Untuk efisiensi dan kelancaran tugas, pada outlet waralaba dan mandiri yang mempunyai lebih dari satu karyawan semua proses pengambilan bahan baku sampai pelayanan kepada konsumen dilakukan karyawan, sedangkan bagi yang mempunyai satu karyawan, pada umumnya kegiatan membeli ayam, mencatat transaksi, mengantarkan ke outlet, berbelanja keperluan outlet dilakukan oleh pemilik, sedangkan karyawan bertugas melakukan penggorengan dan melayani pembeli di outlet saja.

\section{Perbandingan Kelayakan Usaha Outlet Ayam Goreng Waralaba dan Mandiri}

Hasil perbandingan analisis kelayakan usaha ayam goreng waralaba dan mandiri dapat dilihat pada Tabel 5. Pada Tabel 5 terlihat bahwa usaha 
outlet ayam goreng sistem waralaba dan mandiri layak untuk dilaksanakan. Tingkat pengembalian outlet waralaba lebih tinggi daripada outlet mandiri karena pengaturan manajemen operasional yang teratur, terarah dan terencana, menyebabkan sistem waralaba memberikan tingkat pengembalian modal yang lebih cepat daripada yang ditunjukkan dengan Net B/C 4,66 daripada mandiri 1,57. IRR mandiri lebih tinggi karena biaya tetap dan variabel yang harus dikeluarkan oleh outlet mandiri lebih sedikit daripada outlet waralaba. Outlet Sabana 1 yang mempunyai karyawan satu orang mempunyai tingkat pendapatan lebih rendah daripada Sabana 2, karena satu orang tidak selalu mempunyai cukup waktu untuk mengerjakan semua hal sekalipun mampu. Ketika terjadi halangan sementara terhadap karyawan untuk masuk kerja, pemilik yang menggantikan tugas karyawan, tetapi manakala pemilik tidak mempunyai keluasaan waktu untuk menggantikan, maka outlet sementara ditutup. Kepercayaan konsumen akan berkurang ketika terjadi ketidakpastian waktu buka outlet. Sama halnya dengan penelitian Rivai (2012), memajukan dan menumbuhkan bisnis waralaba membutuhkan kredibilitas, kemampuan diferensiasi produk dan jasa yang manajemennya tertata secara baik.

Tabel 5. Perbandingan kelayakan usaha ayam goreng waralaba dan mandiri

\begin{tabular}{|c|c|c|}
\hline \multirow{2}{*}{ Indikator } & \multicolumn{2}{|c|}{ Usaha Ayam Goreng } \\
\hline & Waralaba & Mandiri \\
\hline \multicolumn{3}{|l|}{ a. Keuangan } \\
\hline - NPV (Rp) & 73.192 .780 & 3.703 .077 \\
\hline - IRR & 21,30 & 28,14 \\
\hline - Net B/C & 4,66 & 1,57 \\
\hline - PBP & $\begin{array}{l}\text { satu tahun sembilan bulan dan dua } \\
\text { puluh empat hari }\end{array}$ & $\begin{array}{l}\text { tiga tahun delapan bulan } \\
\text { empat hari }\end{array}$ \\
\hline - Modal Awal (Rp) & 20.000 .000 & 9.250 .000 \\
\hline - Omset/ tahun (Rp) & 180.734 .200 & 91.451 .514 \\
\hline - Laba/ tahun (Rp) & 22.549 .455 & 1.770 .909 \\
\hline \multicolumn{3}{|l|}{ b. Teknis/teknologi } \\
\hline \multirow{2}{*}{ - Lokasi } & Di depan minimarket & Di depan minimarket \\
\hline & $\begin{array}{l}\text { Kompleks perumahan menengah ke } \\
\text { bawah }\end{array}$ & $\begin{array}{l}\text { Kompleks perumahan } \\
\text { menengah ke bawah }\end{array}$ \\
\hline \multirow[t]{2}{*}{ - Peralatan yang dipergunakan } & Kompor & Kompor \\
\hline & Alat penggorengan & Alat penggorengan \\
\hline \multirow[t]{2}{*}{ - Proses pemasakan } & $\begin{array}{l}\text { Bahan baku utama dan tambahan, } \\
\text { harus membeli dari Pewaralaba }\end{array}$ & $\begin{array}{l}\text { Bahan baku utama dan } \\
\text { tambahan membeli dari pasar } \\
\text { tradisional atau penjual ayam } \\
\text { mentah keliling }\end{array}$ \\
\hline & Bumbu harus membeli dari Pewaralaba & Bumbu meracik sendiri \\
\hline \multirow[t]{3}{*}{ c. Manajemen operasional } & $\begin{array}{l}\text { Ada pelatihan karyawan, cara } \\
\text { menggoreng dan melayani pembeli } \\
\text { dari Pewaralaba }\end{array}$ & Latihan diadakan sendiri \\
\hline & $\begin{array}{l}\text { Karyawan mendapatkan baju seragam } \\
\text { Setiap berhasil menjual jumlah } \\
\text { tertentu, mendapatkan bonus } \\
\text { tambahan }\end{array}$ & $\begin{array}{l}\text { Karyawan tidak mendapatkan } \\
\text { baju seragam } \\
\text { Tidak diberlakukan bonus } \\
\text { pencapaian penjualan }\end{array}$ \\
\hline & $\begin{array}{l}\text { Karyawan mendapatkan gaji pokok } \\
\text { dan insentif kehadiran }\end{array}$ & Gaji pokok \\
\hline - Waktu outlet & $11.00-20.00 \mathrm{WIB}$ & $11.00-21.00 \mathrm{WIB}$ \\
\hline - Libur & $\begin{array}{l}\text { Satu pekan sekali dan hari raya Idul } \\
\text { Fitri/Idul Adha. }\end{array}$ & $\begin{array}{l}\text { Satu pekan sekali dan hari raya } \\
\text { Idul Fitri/Idul Adha }\end{array}$ \\
\hline - Absensi & $\begin{array}{l}\text { Karyawan } 1-2 \text { orang, jika salah satu } \\
\text { karyawan berhalangan digantikan oleh } \\
\text { karyawan yang lain/pemilik atau } \\
\text { ditutup. }\end{array}$ & $\begin{array}{l}\text { Karyawan 1-2 orang, jika salah } \\
\text { satu karyawan berhalangan } \\
\text { digantikan oleh karyawan } \\
\text { yang lain/pemilik atau ditutup. }\end{array}$ \\
\hline \multirow{2}{*}{$\begin{array}{l}\text { - Persentase rataan outlet buka } \\
\text { dalam satu bulan sesuai dengan } \\
\text { jadwal buka tahun } 2011\end{array}$} & Sabana $1-85 \%$ & Asoka $-75 \%$ \\
\hline & Sabana $2-95 \%$ & CFC $-90 \%$ \\
\hline
\end{tabular}




\section{Persepsi Konsumen}

Responden yang menjadi obyek penelitian terdiri atas 4 orang nara sumber pemilik outlet ayam goreng, 4 orang nara sumber karyawan outlet ayam goreng dan 120 orang responden konsumen/pembeli produk ayam goreng yang masing-masing terbagi atas 60 konsumen ayam goreng waralaba dan 60 konsumen ayam goreng mandiri. Karakteristik umum responden dapat ditunjukkan dari usia, pekerjaan, jumlah anggota keluarga, pendidikan terakhir, status dalam keluarga dan besar pengeluaran keluarga per bulan.

Berdasarkan data pada Tabel 6, dapat dilihat bahwa responden konsumen ayam goreng waralaba maupun mandiri didominasi oleh kaum perempuan yang sudah menikah, berusia lebih dari 36 tahun dan sebagian besar bekerja sebagai ibu rumah tangga. Pendapatan maupun pengeluaran sebagian besar responden rumah tangga sudah mencapai lebih dari Rp3,9 juta per bulan. Pendidikan responden sebagian besar lulusan Sekolah Lanjutan Tingkat Atas (SLTA) dan perguruan tinggi. Lebih tinggi dari-pada Upah Minimum Regional (UMR) Kabupaten Bogor yaitu 1,3 juta rupiah.

Usia responden yang sebagian besar antara usia 37-46 tahun didominasi oleh kelompok yang secara emosional sudah cukup dewasa. Pekerjaan sebagai ibu rumah tangga, karena di kompleks perumahan sebagian besar suami sebagai pekerja di luar kompleks. Sebagian besar responden berpendidikan diploma/sarjana, semakin menguatkan daya rasionalitas responden ketika melakukan pengisian kuesioner.

Tabel 6. Karakteristik umum responden ayam goreng

\begin{tabular}{|c|c|c|c|c|c|}
\hline \multirow[b]{2}{*}{ No. } & \multirow[b]{2}{*}{ Karakteristik responden } & \multicolumn{2}{|c|}{ Waralaba } & \multicolumn{2}{|c|}{ Mandiri } \\
\hline & & $\begin{array}{l}\text { Jumlah } \\
\text { (orang) }\end{array}$ & $\begin{array}{c}\text { Persentase } \\
(\%)\end{array}$ & $\begin{array}{l}\text { Jumlah } \\
\text { (orang) }\end{array}$ & $\begin{array}{c}\text { Persentase } \\
(\%)\end{array}$ \\
\hline \multirow[t]{3}{*}{1} & Jenis kelamin & & & & \\
\hline & Laki-laki & 3 & 5 & 8 & 13 \\
\hline & Perempuan & 57 & 95 & 52 & 87 \\
\hline \multirow[t]{5}{*}{2} & Usia (tahun) & & & & \\
\hline & $17-26$ & 6 & 10 & 8 & 13 \\
\hline & $27-36$ & 23 & 38 & 20 & 33 \\
\hline & $37-46$ & 31 & 52 & 28 & 47 \\
\hline & $>47$ & & & 4 & 7 \\
\hline \multirow[t]{5}{*}{3} & Pekerjaan & & & & \\
\hline & Mahasiswa/Pelajar/PNS/Swasta & 6 & 10 & 9 & 15 \\
\hline & Wirausaha & 3 & 6 & 8 & 13 \\
\hline & Ibu rumah tangga & 38 & 63 & 39 & 65 \\
\hline & Lainnya, & 13 & 21 & 4 & 7 \\
\hline \multirow[t]{4}{*}{4} & Pendapatan keluarga/bulan (Rp) & & & & \\
\hline & $<1.300 .000$ & 11 & 18 & 5 & 9 \\
\hline & $1.300 .000-3.900 .000$ & 7 & 12 & 14 & 23 \\
\hline & $>3.900 .000$ & 42 & 70 & 41 & 68 \\
\hline \multirow[t]{4}{*}{5} & Pengeluaran keluarga/bulan (Rp) & & & & \\
\hline & $<1.300 .000$ & 15 & 25 & 12 & 20 \\
\hline & $1.300 .000-3.900 .000$ & 10 & 17 & 9 & 15 \\
\hline & $>3.900 .000$ & 35 & 58 & 39 & 65 \\
\hline \multirow[t]{5}{*}{6} & Pendidikan terakhir & & & & \\
\hline & $\mathrm{SD}$ & 1 & 2 & 1 & 2 \\
\hline & SLTP & 7 & 11 & 6 & 10 \\
\hline & SLTA & 18 & 30 & 24 & 40 \\
\hline & Diploma/Sarjana & 34 & 57 & 29 & 48 \\
\hline \multirow[t]{4}{*}{7} & Status pernikahan & & & & \\
\hline & Belum menikah & 6 & 10 & 8 & 13 \\
\hline & Sudah menikah & 54 & 90 & 49 & 82 \\
\hline & Pernah menikah & & & 3 & 5 \\
\hline
\end{tabular}


Perbandingan Perilaku Konsumen pada Usaha Outlet Ayam Goreng Waralaba dan Mandiri

Berdasarkan Engel et al., (1994) terdapat lima tahapan proses keputusan pembelian konsumen, yaitu (a) pengenalan kebutuhan, (b) pencarian informasi, (c) evaluasi alternatif, (d) pembelian dan (e) perilaku setelah pembelian.

\section{a. Pengenalan kebutuhan}

Hasil analisis menunjukkan keseluruhan responden menyatakan bahwa manfaat yang dicari dari pembelian ayam goreng waralaba dan mandiri adalah praktis dan terjamin mutunya. Manfaat dominan yang dicari dari pembelian ayam goreng mandiri adalah kepraktisan. Responden waralaba memilih 57\%, sedangkan mandiri $80 \%$. Perbandingan manfaat ini bisa dilihat pada Gambar 1.

Waralaba

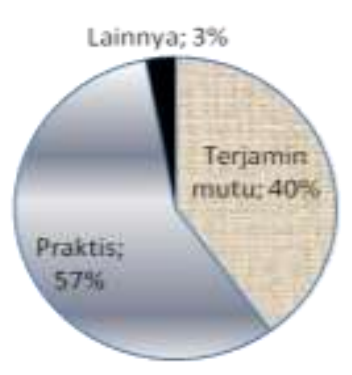

Gambar 1. Persentase manfaat yang dirasakan konsumen ayam goreng waralaba dan mandiri

Setelah diketahui manfaat yang dicari, maka ada beberapa motivasi tertentu yang mendorong konsumen dalam pembelian ayam goreng. Responden waralaba memilih faktor harga (42\%), kemudahan memperoleh (22\%), higienis (15\%), mutu (13\%), serta faktor lain seperti kemasan dan pelayanan $(7 \%)$. Motivasi dominan yang mendorong konsumen dalam pembelian ayam goreng mandiri adalah harga (39\%), faktor kemudahan memperoleh produk $(25 \%)$, higienis $(18 \%)$, mutu (10\%) dan pelayanan $(8 \%)$.

Harga menjadi pertimbangan awal dalam pembelian bagi kedua outlet karena konsumen ibu rumah tangga cukup rentan dengan selisih harga walaupun kecil. Konsumen yang tinggal di kompleks perumahan menengah ke bawah, pertimbangan semacam itu wajar. Persentase motivasi pembelian dapat dilihat pada Gambar 2.

\section{b. Pencarian informasi}

Hasil kajian menunjukkan, baik konsu-men ayam goreng waralaba dan mandiri memperoleh informasi secara internal. Respon-den waralaba memberikan jawaban tersebut $60 \%$ dan responden mandiri $35 \%$. Sumber informasi lainnya (teman, keluarga, dan orang lain) menjadi faktor kecil dari sumber informasi (Gambar 3).

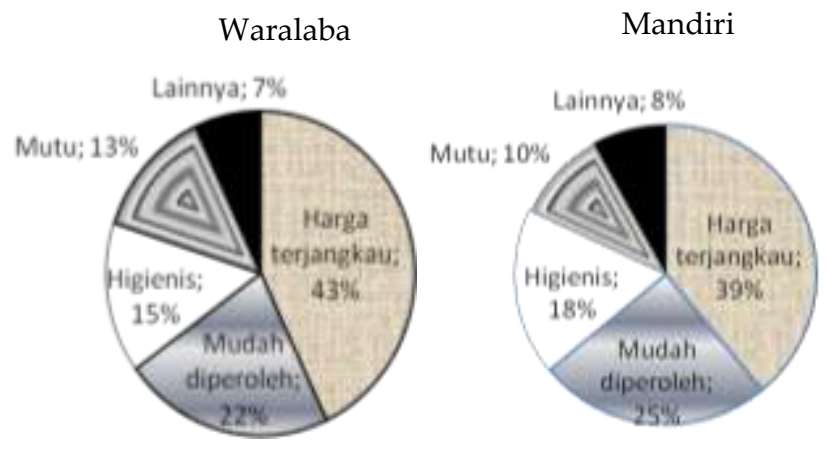

Gambar 2. Persentase motivasi pembelian konsumen ayam goreng waralaba dan mandiri
Waralaba

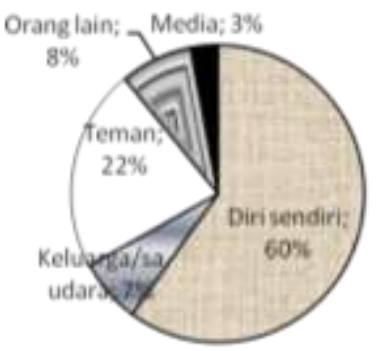

Mandiri

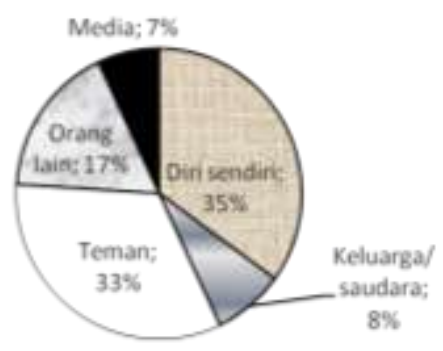

Gambar 3. Persentase sumber informasi konsumen ayam goreng waralaba dan mandiri

\section{c. Evaluasi alternatif}

Harga merupakan hal utama yang menjadi pertimbangan awal bagi konsumen dalam pembelian. Responden ayam goreng waralaba memilih harga (60\%) sebagai faktor dominan. Selain itu, faktor mudah didapatkan/ diperoleh (25\%) menjadi pertimbangan awal konsumen dalam pembelian ayam goreng waralaba. Faktor utama yang menjadi pertimbangan awal konsumen dalam membeli ayam goreng mandiri adalah harga $(38 \%)$ dan mudah diperoleh (37\%). Selengkapnya dapat dilihat pada Gambar 4.

Bukti lain yang menunjukkan peubah harga ini cukup penting adalah dengan pilihan konsumen untuk pindah ke outlet yang lain seandainya harga ayam goreng di outlet dinaikkan. Kemampuan pengelola outlet untuk mencermati loyalitas konsumen pada harga ini harus dijadikan perhatian yang cukup serius. 
Saat ini, outlet yang berada di area mini market tidak diperbolehkan menjual jenis barang yang sama, maka bagi pengusaha outlet ayam goreng cukup aman, karena tidak ada pengusaha lain yang berjualan jenis barang sama di area dan sekitar mini market.

Waralaba

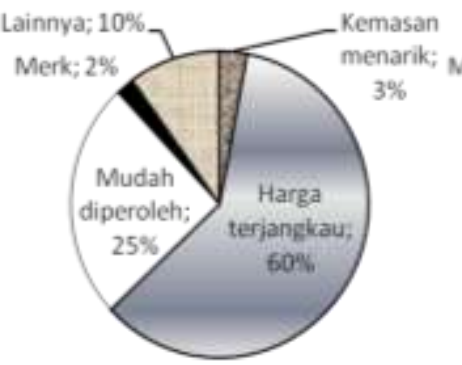

Gambar 4. Persentase alternatif pertimbangan konsumen membeli ayam goreng waralaba dan mandiri

\section{d. Proses pembelian}

Berdasarkan Gambar 5, dapat diketahui bahwa dalam rumah tangga konsumen ayam goreng waralaba, menyatakan bahwa keputusan pembelian lebih banyak dipengaruhi oleh anak-anak (40\%) dan ibu/istri (37\%). Pada ayam goreng mandiri, penyebab melakukan pembelian oleh anak anak (45\%) dan ibu/istri $(37 \%)$
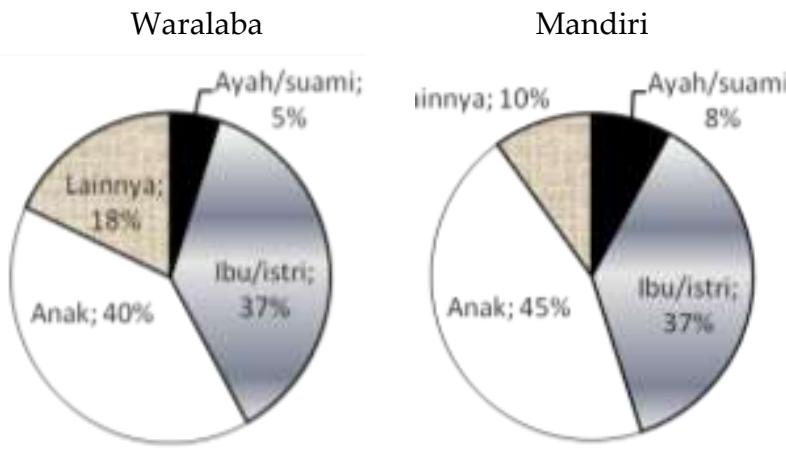

Gambar 5. Persentase penentu keputusan pembelian ayam goreng waralaba dan mandiri

Gambar 6 menunjukkan penyebab kebanyakan konsumen membeli ayam goreng waralaba adalah tidak terencana sebelumnya. Konsumen ayam goreng waralaba $42 \%$ dan mandiri 57\% menyatakan bahwa pembelian dilakukan secara mendadak karena merasa perlu atau sekedar singgah ke outlet ayam goreng. Konsumen melakukan pembelian pada saat sedang berkunjung pada suatu tempat di daerah yang berdekatan dengan lokasi outlet, tidak sedang memasak untuk keluarga di rumah atau secara mendadak anak menginginkan menu ayam goreng.

\section{e. Perilaku setelah pembelian}

Berdasarkan Gambar 7, diketahui bahwa $88 \%$ konsumen waralaba menyatakan puas, $12 \%$ menyatakan tidak puas. Semakin besar kepuasan konsumen, maka semakin besar peluang melakukan pembelian ulang. Hal tersebut dapat disimpulkan bahwa kepuasan terhadap produk atau jasa yang diberikan memengaruhi pada pembelian selanjutnya menimbulkan kesetiaan terhadap merek. Diketahui bahwa dari 60 responden ayam goreng mandiri, 90\% di antaranya menyatakan kepuasan, $10 \%$ menyatakan ketidakpuasan. Tingkat kepuasan terhadap produk atau jasa yang diberikan mempengaruhi pada pembelian yang selanjutnya menimbulkan kesetiaan terhadap merek.

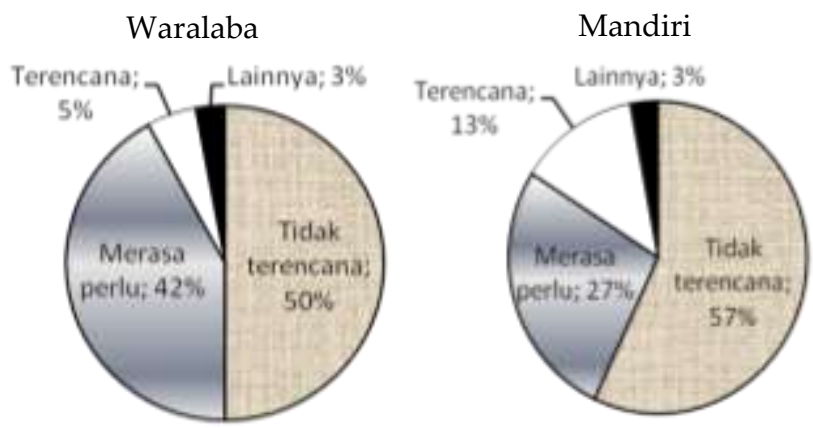

Gambar 6. Persentase penyebab keputusan pembelian ayam goreng waralaba dan mandiri
Waralaba

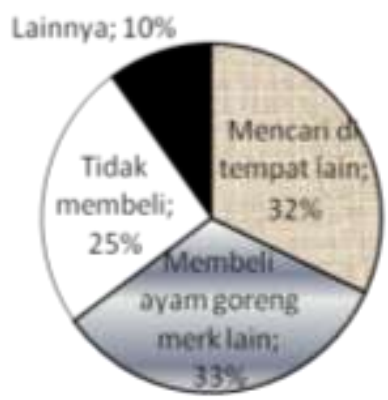

Mandiri

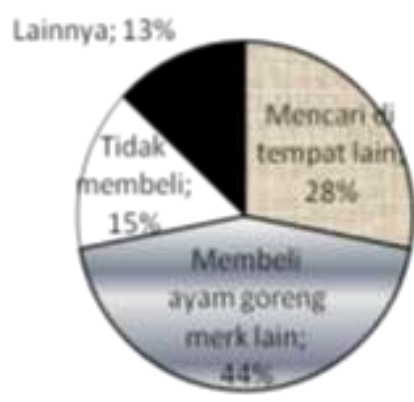

Gambar 7. Persentase tingkat loyalitas konsumen ayam goreng waralaba dan mandiri

Hasil kuesioner terhadap 60 responden ayam goreng waralaba menyatakan tindakan konsumen, jika harga di outlet tersebut mengalami kenaikan harga, maka sebanyak 33\% menyatakan akan membeli ayam goreng merek lain. Dari 60 responden ayam goreng mandiri, sebagian besar 
menyatakan akan membeli ayam goreng merek lain atau akan mencari di tempat lain produk ayam goreng mandiri apabila tidak ada produk ayam goreng mandiri pada outlet atau produk mengalami kenaikan harga (Gambar 7).

Walaupun hampir semua konsumen mengaku puas dengan produk ayam goreng outlet waralaba dan mandiri, perlu dijadikan nilai tambah sekaligus kewaspadaan bagi pengusaha bahwa penilaian itu muncul karena kurangnya persaingan di area yang sama atau area terdekat. Seandainya terdapat penjual jenis produk yang sama di dekat area mini market mungkin situasinya bisa berbeda.

Kombinasi terhadap pilihan konsumen bahwa faktor harga, jaminan mutu dan higienes/ kebersihan merupakan faktor pertimbangan di atas 50\% dari semua outlet waralaba dan mandiri, menegaskan bahwa adanya nama merek tertentu, dan kemasan yang menarik kurang mendapatkan minat bagi konsumen outlet ayam goreng. Kesepakatan tidak tertulis bahwa merek yang terkenal dan ketertarikan terhadap kemasan adalah untuk konsumsi kelas menengah ke atas ternyata mendapatkan kesesuaian data.

Kepercayaan pada pemilik outlet mendapatkan cukup banyak pilihan. Pada outlet waralaba $46 \%$ dan mandiri 33\%. Hal ini menunjukkan bahwa penilaian bagi pengusaha yang tinggal di kompleks perumahan menjadi perhatian cukup penting dan tidak terlepas dari sorotan pembeli, apalagi jika diketahui sebagian besar pembeli adalah ibu rumah tangga, walaupun nilai persentase kurang dari $50 \%$. Cerminan bagi para pengusaha untuk menjaga citra baik di kalangan warga kompleks perumahan sebagai suatu simbol kepercayaan.

\section{Strategi Pengembangan Usaha}

Berdasarkan hasil analisis lingkungan, baik internal maupun eksternal, usaha ayam goreng berupa faktor kekuatan dan kelemahan, serta faktor peluang dan ancaman yang berpengaruh terhadap pengembangan usaha, ditetapkan posisi usaha ayam goreng waralaba menggunakan matriks IFE dan EFE, serta dirumuskan strategi yang akan diterapkan dengan analisis SWOT dan QSPM. Proses manajemen strategik pada hakikatnya adalah serangkaian penuh komitmen, keputusan dan tindakan yang diperlukan sebuah perusahaan untuk mencapai daya saing strategik dan mendapatkan laba di atas rataan (Lee and Tsai, 2005).

\section{Faktor Internal}

Kekuatan yang diidentifikasi terdiri dari manajemen usaha berjalan baik, lokasi yang nyaman dan strategik, tersedianya bahan baku, alat produksi memadai dan kecepatan pelayanan. Dalam kegiatan operasionalnya, suatu usaha dituntut untuk selalu melakukan tindakan yang efektif dan efisien, dikarenakan dalam bisnis/ usaha, selain produk yang dijual, faktor pelayanan atau jasa juga diperhitungkan. Untuk itu suatu usaha perlu menerapkan manajemen usaha yang baik, yaitu mulai dari perencanaan usaha, modal, pengadaan bahan baku proses pengolahan sampai dengan penyajian kepada konsumen. Usaha ayam goreng waralaba, secara manajemen sudah terbentuk, sehingga terwaralaba bisa langsung meniru manajemen pewaralaba.

Seperti halnya pada ayam goreng waralaba, faktor-faktor yang menjadi kekuatan usaha ayam goreng mandiri terdiri dari manajemen usaha berjalan baik, lokasi yang nyaman dan strategik, tersedianya bahan baku, alat produksi memadai, dan kecepatan pelayanan. Yang menjadi kelemahan usaha ayam goreng mandiri adalah modal usaha terbatas, biaya produksi meningkat, kapasitas produksi terbatas dan kurangnya promosi.

\section{Faktor Eksternal}

Peluang yang diidentifikasi terdiri dari jumlah konsumen yang semakin meningkat, kemitraan dengan pemasok bahan baku yang harmonis, pemasaran ayam goreng terbuka lebar, perubahan gaya hidup dan perekonomian semakin baik. Ancaman yang dihadapi terdiri dari kesadaran konsumen terhadap mutu, tingkat persaingan usaha yang ketat, daya saing dan citra produk meningkat, akses permodalan lemah dan isu flu burung. Dengan jumlah penduduk hampir men-capai lima juta jiwa di wilayah Bogor, telah menjadi salah satu wilayah sasaran penjualan produk, atau pangsa pasar yang besar, memberikan peluang besar untuk meningkatkan penjualan produk ayam goreng waralaba.

\section{Matriks IFE dan EFE}

\section{IFE}

Matriks IFE menggambarkan kondisi internal usaha yang terdiri dari kekuatan dan kelemahan yang dihitung berdasarkan rating dan bobot melalui kuesioner dari pemilik dan karyawan usaha ayam goreng waralaba. Tabel 7 menunjukkan matriks IFE yang menganalisis sembilan faktor sukses kritis yang terdiri dari lima kekuatan dan empat kelemahan. 
Berdasarkan hasil analisis matriks IFE pada Tabel 16 terlihat faktor kekuatan utama usaha waralaba adalah manajemen usaha yang telah berjalan dengan baik $(0,534)$, dikarenakan pada bentuk usaha waralaba manajemen usaha sudah diatur atau mengikuti manajemen pewaralaba. Manajemen berfungsi untuk mengatur agar segala hal dapat berjalan dengan baik. Kelemahan utama adalah kurangnya promosi dengan nilai tertimbang terkecil $(0,097)$. Waralaba dikembangkan melalui sistem jaringan dari mulut ke mulut, tanpa seorangpun menyadari bahwa suatu pengembangan usaha melalui promosi atas inovasi produk akan menentukan perkembangan usaha. Promosi sangat diperlukan untuk pengenalan produk dan pengembangan usaha baik melalui orang per orang ataupun media massa. Hasil penelitian Bridges et al. (2009), Nagar (2010) dan Omotayo (2011) menemukan bahwa promosi penjualan adalah faktor penting dalam menentukan loyalitas pelanggan dan mampu memengaruhi secara langsung minat pelanggan untuk melakukan pembelian ulang pada masa mendatang.

Tabel 7. Faktor internal usaha ayam goreng waralaba dan mandiri

\begin{tabular}{|c|c|c|c|}
\hline & Faktor Internal & $\begin{array}{c}\text { Skor } \\
\text { Waralaba }\end{array}$ & $\begin{array}{l}\text { Skor } \\
\text { Mandiri }\end{array}$ \\
\hline \multicolumn{4}{|c|}{ Kekuatan } \\
\hline A & $\begin{array}{l}\text { Manajemen usaha } \\
\text { berjalan baik }\end{array}$ & 0,534 & 0,261 \\
\hline B & $\begin{array}{l}\text { Lokasi nyaman dan } \\
\text { strategik }\end{array}$ & 0,462 & 0,482 \\
\hline C & Tersedianya bahan baku & 0,375 & 0,316 \\
\hline $\mathrm{D}$ & Alat produksi memadai & 0,449 & 0,293 \\
\hline $\mathrm{E}$ & Kecepatan pelayanan & 0,430 & 0,328 \\
\hline \multicolumn{4}{|c|}{ Kelemahan } \\
\hline $\mathrm{F}$ & Modal usaha terbatas & 0,191 & 0,141 \\
\hline G & $\begin{array}{l}\text { Biaya produksi } \\
\text { meningkat }\end{array}$ & 0,148 & 0,222 \\
\hline $\mathrm{H}$ & $\begin{array}{l}\text { Kapasitas produksi } \\
\text { terbatas }\end{array}$ & 0,229 & 0,231 \\
\hline \multirow[t]{2}{*}{ I } & Kurang promosi & 0,097 & 0,221 \\
\hline & TOTAL & 2,916 & 2,495 \\
\hline
\end{tabular}

Matriks IFE untuk usaha ayam goreng mandiri menunjukkan bahwa faktor yang menjadi kekuatan utama adalah lokasi nyaman dan strategic $(0,482)$. Lokasi di depan mini market dalam kompleks perumahan menjadi kekuatan ayam goreng mandiri. Konsumen sebagian besar warga kompleks perumahan yang membutuhkan ketersediaan barang ketika diperlukan. Kecepatan dalam memberikan pelayanan termasuk dalam faktor lokasi yang strategis karena konsumen lebih menyukai jarak yang dekat dengan rumah. Kelemahan utamanya adalah modal usaha yang terbatas $(0,141)$. Outlet terwaralaba mandiri didirikan oleh pengusaha yang mempunyai misi menjadi pewaralaba, tetapi terhambat oleh terbatasnya modal yang dimiliki. Keterbatasan modal ini mempengaruhi kemampuan untuk menggantikan biaya yang timbul tatkala penjualan sedang sepi.

Faktor internal ayam goreng waralaba dengan total skor 2,916 dan ayam goreng mandiri dengan total skor 2,495 menunjukan keduanya mampu memanfaatkan kekuatan internal untuk mengatasi kelemahan.

\section{EFE}

Matriks EFE menggambarkan kondisi eksternal usaha yang terdiri dari peluang dan ancaman. Tabel 8 menunjukkan matriks EFE yang menganalisis 10 faktor sukses kritis yang terdiri dari lima peluang dan lima ancaman

Tabel 8. Faktor eksternal usaha ayam goreng waralaba dan mandiri

\begin{tabular}{|c|c|c|c|}
\hline & $\begin{array}{c}\text { FAKTOR } \\
\text { EKSTERNAL }\end{array}$ & $\begin{array}{c}\text { Skor } \\
\text { Waralaba }\end{array}$ & $\begin{array}{c}\text { Skor } \\
\text { Mandiri }\end{array}$ \\
\hline \multicolumn{4}{|c|}{ Peluang } \\
\hline A & $\begin{array}{l}\text { Konsumen yang } \\
\text { semakin meningkat }\end{array}$ & 0,458 & 0,329 \\
\hline B & $\begin{array}{l}\text { Kemitraan dengan } \\
\text { pemasok bahan baku } \\
\text { yang harmonis }\end{array}$ & 0,298 & 0,350 \\
\hline C & $\begin{array}{l}\text { Pemasaran ayam } \\
\text { goreng terbuka lebar }\end{array}$ & 0,334 & 0,302 \\
\hline $\mathrm{D}$ & Perubahan gaya hidup & 0,349 & 0,321 \\
\hline $\mathrm{E}$ & $\begin{array}{l}\text { Perekenomian semakin } \\
\text { baik }\end{array}$ & 0,221 & 0,226 \\
\hline \multicolumn{4}{|c|}{ Ancaman } \\
\hline $\mathrm{F}$ & $\begin{array}{l}\text { Kesadaran konsumen } \\
\text { terhadap mutu }\end{array}$ & 0,200 & 0,085 \\
\hline G & $\begin{array}{l}\text { Tingkat persaingan } \\
\text { usaha yang ketat }\end{array}$ & 0,165 & 0,181 \\
\hline $\mathrm{H}$ & $\begin{array}{l}\text { Daya saing dan citra } \\
\text { produk meningkat }\end{array}$ & 0,175 & 0,225 \\
\hline I & $\begin{array}{l}\text { Akses permodalan } \\
\text { lemah }\end{array}$ & 0,264 & 0,222 \\
\hline $\mathrm{J}$ & Isu flu burung & 0,217 & 0,160 \\
\hline & TOTAL & 2,681 & 2,402 \\
\hline
\end{tabular}

Analisis matriks EFE menunjukkan bahwa faktor yang menjadi peluang utama pada usaha ayam goreng mandiri adalah kemitraan dengan pemasok bahan baku yang harmonis $(0,350)$. Hal ini menjadi penting, karena hubungan baik dengan pemasok untuk menjaga kontinuitas kelangsungan penjualan, mendapatkan harga di 
bawah harga pasar. Sementara pada ayam goreng waralaba adalah konsumen yang semakin meningkat $(0,458)$.

Ancaman terbesarnya adalah kesadaran konsumen terhadap mutu dengan nilai 0,085. Konsumen perumahan yang sebagian besar lulusan sarjana/diploma mulai memahami tentang risiko terhadap kesehatan akibat penggunaan minyak goreng secara berulang bisa mengganggu kesehatan. Pemilik ayam goreng mandiri harus melakukan antisipasi dengan membuat jadwal penggantian penggunaan minyak goreng secara teratur. Pada ayam goreng waralaba, yang menjadi ancaman utamanya adalah Tingkat persaingan usaha yang ketat $(0,165)$.

Total skor EFE ayam goreng waralaba 2,681 dan ayam goreng mandiri 2,402 menunjukkan posisi eksternal yang kuat, karena mampu memanfaatkan peluang untuk mengatasi ancaman.

\section{Matriks Internal-Eksternal}

Berdasarkan analisis matriks IFE ayam goreng waralaba didapatkan nilai skor 2,916 dan matriks EFE 2,681, menempatkan usaha ayam goreng waralaba masuk pada sel $\mathrm{V}$ dalam matriks IE. Hal ini menunjukkan bahwa perusahaan berada pada posisi Hold and Maintain (pertahankan dan pelihara), maka digunakan strategi penetrasi pasar dan pengembangan produk.

Analisis matriks IFE dan EFE usaha ayam goreng mandiri menghasilkan nilai IFE 2,495 dan nilai EFE 2,402, yang menunjukkan posisi eksternal usaha rataan dalam memanfaatkan peluang dan mengatasi ancaman yang ada. Berdasarkan hasil tersebut, usaha ayam goreng mandiri berada pada sel V dari matriks IE. Hal ini menunjukkan bahwa usaha ayam goreng mandiri berada pada posisi Hold and Maintain (pertahankan dan pelihara), maka digunakan penetrasi pasar dan pengembangan produk.

\section{Matriks SWOT}

Uraian strategi pada Matriks SWOT ayam goreng waralaba dapat dilihat pada Gambar 8. Pada tabel tersebut diketahui alternatif strategi yang dapat dilakukan untuk penetrasi pasar dan pengembangan produk, yaitu:

1) Strategi kekuatan dan peluang (strengthsopportunities): Menjaga loyalitas konsumen dengan mengoptimalkan mutu produk dan pelayanan (S1,S2,S5, O1,O3,O4,O5).

Meningkatkan loyalitas konsumen terhadap suatu usaha/perusahaan sangat penting, dalam hal ini adalah usaha ayam goreng wara- laba harus memberikan yang terbaik untuk konsumen, baik dari segi kualitas produk maupun pelayanannya.

2) Strategi kelemahan dan peluang (weaknessesopportunities): Melakukan promosi melalui penyebaran leaflet, radio lokal dan internet. kerja sama dengan komunitas perumahan, menjalin kemitraan dengan perusahaan yang lebih besar (W4,W1, O1,O3,O4,O5).

3) Strategi kekuatan dan ancaman (strengthsthreats): Menjaga brand image (S1,S2,S5,T2,T1,T5)

Dengan banyak pesaing pada usaha sejenis, penjagaan image produk harus dilakukan, diantaranya dengan konsisten mempertahankan kelezatan dan cita rasa cryspy yang bersih dengan tidak lembek setelah penggorengan dan mengoptimalkan pelayanan dengan bersikap ramah, serta menggunakan kaos tangan ketika transaksi.

4) Strategi kelemahan dan ancaman (weaknessestreaths): Menghadiri dan mengikuti pameranpameran makanan (W4,W1,T2,T1, T3)

Melakukan promosi melalui kegiatan pameran-pameran makanan atau terlibat memberikan hadiah pada acara peringatan hari kemerdekaan di perumahan, memasang banner produk, kerjasama acara khitanan, pesta pernikahan dan kegiatan lain yang sejenis dapat meningkatkan pengetahuan tentang produk agar lebih dikenal di masyarakat.

Berdasarkan matriks SWOT usaha ayam goreng mandiri (Gambar 9), maka alternatif strategi yang dapat dilakukan untuk penetrasi pasar dan pengembangan produk adalah:

1) Strategi kekuatan dan peluang (strengthsopportunities): Mempertahankan kesetiaan konsumen dan hubungan baik dengan pemasok (S2,S3,S5,O2,O1,O3).

Strategi ini dapat dilakukan dengan memberikan yang terbaik untuk konsumen, baik dari segi mutu produk maupun pelayanannya. Menjaga hubungan baik dengan pemasok, dilakukan dengan menjalin hubungan dengan pemasok, antara lain melakukan pembelian bahan baku secara kolektif, sehingga bahan baku tetap terjaga dan mampu menjamin kontinuitas ketersediaan bahan baku, membuat kesepakatan harga maksimum antar pemilik outlet.

2) Strategi kelemahan dan peluang (weaknessesopportunities): Gencar melakukan pencarian alternatif tambahan modal (W1,W2,W3,W4, $\mathrm{O} 2, \mathrm{O} 1, \mathrm{O} 3)$. 
Modal adalah hal mutlak yang harus dimiliki untuk pengembangan usaha. Pegiat usaha ayam goreng mandiri harus melakukan pencarian alternatif untuk mendapatkan modal, baik lewat lembaga keuangan perbankan, koperasi, lembaga keuangan mikro, maupun lembaga keuangan lain.

\begin{tabular}{|c|c|c|}
\hline Faktor Eksternal & $\begin{array}{l}\quad \text { Kekuatan }(\mathrm{S}) \\
\text { 1. Manajemen usaha berjalan baik } \\
\text { 2. Lokasi nyaman dan strategik } \\
\text { 3. Tersedianya bahan baku } \\
\text { 4. Alat produksi memadai } \\
\text { 5. Kecepatan pelayanan }\end{array}$ & $\begin{array}{l}\quad \text { Kelemahan }(\mathrm{W}) \\
\text { 1. Modal usaha terbatas } \\
\text { 2. Biaya produksi meningkat } \\
\text { 3. Kapasitas produksi terbatas } \\
\text { 4. Kurang promosi }\end{array}$ \\
\hline $\begin{array}{l}\qquad \text { Peluang }(\mathrm{O}) \\
\text { 1. Konsumen yang semakin meningkat } \\
\text { 2. Kemitraan dengan pemasok bahan } \\
\text { baku yang harmonis } \\
\text { 3. Pemasaran ayam goreng terbuka } \\
\text { lebar } \\
\text { 4. Perubahan gaya hidup } \\
\text { 5. Perekenomian semakin baik }\end{array}$ & \begin{tabular}{l}
\multicolumn{1}{c}{ Strategi S-O } \\
Menjaga loyalitas konsumen \\
dengan mengoptimalkan mutu \\
produk dan pelayanan dengan \\
cara menjaga rasa tetap crispy dan \\
mempercepat proses transaksi \\
$(\mathrm{S} 1, \mathrm{~S} 2, \mathrm{~S} 5, \mathrm{O} 1, \mathrm{O} 3, \mathrm{O} 4, \mathrm{O} 5)$
\end{tabular} & \begin{tabular}{l}
\multicolumn{1}{c}{ Strategi W-O } \\
Promosi melalui penyebaran \\
leaflet, radio lokal dan internet, \\
kerja sama dengan komunitas \\
perumahan, menjalin \\
kemitraan dengan perusahaan \\
yang lebih besar \\
(W4,W1,O1,O3,O4,O5)
\end{tabular} \\
\hline $\begin{array}{l}\qquad \text { Ancaman }(\mathrm{T}) \\
\text { 1. Kesadaran konsumen terhadap mutu } \\
\text { 2. Tingkat persaingan usaha yang ketat } \\
\text { 3. Daya saing dan citra produk } \\
\text { meningkat } \\
\text { 4. Akses permodalan lemah } \\
\text { 5. Isu flu burung }\end{array}$ & \begin{tabular}{l}
\multicolumn{1}{c}{ Strategi S-T } \\
Menjaga brand image dengan \\
menjaga harga tetap murah dan \\
petugas menggunakan kaos \\
tangan ketika melayani pembeli, \\
ramah (S1, S2,S5,T2,T1,T5)
\end{tabular} & $\begin{array}{l}\text { Strategi W-T } \\
\text { Menghadiri dan mengikuti } \\
\text { pameran-pameran makanan, } \\
\text { konsolidasi usaha antar } \\
\text { terwaralaba ayam goreng, } \\
\text { memasang banner, aktif pada } \\
\text { kegiatan warga. } \\
\text { (W4,W1,T2,T1, T3) }\end{array}$ \\
\hline
\end{tabular}

Gambar 8. Matriks SWOT usaha ayam goreng waralaba

\begin{tabular}{|c|c|c|}
\hline Faktor Internal & $\begin{array}{l}\quad \text { Kekuatan }(\mathrm{S}) \\
\text { 1. Manajemen usaha berjalan } \\
\text { baik } \\
\text { 2. Lokasi nyaman dan strategik } \\
\text { 3. Tersedianya bahan baku } \\
\text { 4. Alat produksi memadai } \\
\text { 5. Kecepatan pelayanan }\end{array}$ & $\begin{array}{l}\quad \text { Kelemahan }(\mathrm{W}) \\
\text { 1. Modal usaha terbatas } \\
\text { 2. Biaya produksi meningkat } \\
\text { 3. Kapasitas produksi } \\
\text { terbatas } \\
\text { 4. Kurang promosi }\end{array}$ \\
\hline \begin{tabular}{ll}
\multicolumn{1}{c}{ Peluang $(\mathrm{O})$} \\
1. Konsumen yang semakin \\
meningkat \\
2. Kemitraan dengan pemasok \\
bahan baku yang harmonis \\
3. Pemasaran ayam goreng terbuka \\
lebar \\
4. Perubahan gaya hidup \\
5. Perekonomian semakin baik
\end{tabular} & \begin{tabular}{l}
\multicolumn{1}{c}{ Strategi S-O } \\
Mempertahankan kesetiaan \\
konsumen dan hubungan baik \\
dengan pemasok. dengan \\
kesepakatan harga maksimum, \\
pembelian bahan baku secara \\
kolektif, antar outlet \\
(S2,S3,S5,O2,O1,O3)
\end{tabular} & \begin{tabular}{l}
\multicolumn{1}{c}{ Strategi W-O } \\
Gencar melakukan pencarian \\
alternatif tambahan modal \\
melalui pembentukan \\
kelompok outlet mandiri \\
untuk mengurangi biaya \\
bahan baku. \\
(W1,W2,W3,W4,O2,O1,O3)
\end{tabular} \\
\hline \begin{tabular}{ll}
\multicolumn{1}{c}{ Ancaman (T) } \\
1. Kesadaran konsumen terhadap \\
mutu \\
2. Tingkat persaingan usaha yang \\
ketat \\
3. Daya saing dan citra produk \\
meningkat \\
4. Akses permodalan lemah \\
5. Isu flu burung
\end{tabular} & \begin{tabular}{l}
\multicolumn{1}{c}{ Strategi S-T } \\
Meningkatkan mutu produk dan \\
layanan dengan cara membuat \\
produk tetap cryspy dan ramah \\
pada pembeli. $(\mathrm{S} 1, \mathrm{~S} 2, \mathrm{~S} 5, \mathrm{~T} 2, \mathrm{~T} 1, \mathrm{~T} 5)$
\end{tabular} & \begin{tabular}{l}
\multicolumn{1}{c}{ Strategi $\mathrm{W}-\mathrm{T}$} \\
Melakukan promosi, \\
terutama melalui internet, \\
penyebaran leaflet, radio \\
lokal (W1,W2,W4,T1,T2, T4)
\end{tabular} \\
\hline
\end{tabular}


3) Strategi kekuatan dan ancaman (strengthsthreats): Meningkatkan mutu produk dan layanan (S1,S2,S5,T2,T1,T5).

Agar dapat bersaing dengan usaha sejenis maupun usaha ayam goreng waralaba yang sudah memiliki mutu yang diakui, maka usaha ayam goreng mandiri harus mulai mempertahankan konsistensi kelezatan, cita rasa dan mutu produk dengan tetap menjaga produk tetap cryspy dan mengoptimalkan pelayanan dengan cara bersikap ramah kepada pembeli.

4) Strategi kelemahan dan ancaman (weaknessesthreats): Melakukan promosi sendiri, terutama melalui internet, penyebaran leaflet, dan radio lokal (W1,W2,W4,T1,T2, T4).

Adanya keterbatasan dana (modal yang terbatas), maka usaha promosi dilakukan sendiri dengan mengefisienkan biaya. Promosi usaha ayam goreng yang paling murah adalah lewat mulut ke mulut, kemudian memanfaatkan internet, leaflet sederhana, dan radio lokal.

Posisi yang sama di kuadran V membuktikan bahwa pada dasarnya manajemen outlet ayam goreng waralaba dan mandiri sudah pada posisi bagus secara pengelolaan, walaupun masing masing mempunyai keunggulan relatif. Posisi S$O$ yang menjadikan, baik waralaba dan mandiri perlu menjaga loyalitas konsumen di kompleks perumahan kelas menengah ke bawah, tidak ada persaingan yang cukup berarti di sekitar mini market. Perilaku konsumen yang setia pada harga, mutu produk terjamin, kebersihan harus dijaga. Perlu dipikirkan secara cermat ketika suatu saat terjadi peningkatan harga peubah terhadap biaya produksi bahan baku, terutama harga gas, bahan baku daging ayam mentah. Menghadiri dan mengikuti pameran makanan membuat outlet waralaba tidak kehilangan jati diri, karena mendapatkan informasi baru mengenai perkembangan outlet ayam goreng di tempat lain. Bagi outlet mandiri, hubungan baik dengan pemasok perlu dijaga supaya tidak terjadi keko-songan pasokan ketika terjadi fluktuasi harga bahan baku.

Strategi W-O pada outlet waralaba segera digencarkan dengan penyebaran leaflet, radio lokal, internet untuk menunjukkan positioning dari produk ayam goreng, sedangkan bagi mandiri membina jaringan dengan lembaga-lembaga atau pribadi di luar untuk mencari pendanaan tambahan guna meningkatkan mutu persaingan, karena secara pondasi dasar outlet mandiri lebih efisien secara biaya. Brand image waralaba perlu diantisipasi, karena konsumen tidak terlalu mempermasalahkan merk, maka organisasi modern perlu melakukan penjagaan merk melalui citra sebagai faktor penentu utama pada masa mendatang. Wang et al. (2012) menemukan bahwa citra perusahaan memiliki hubungan langsung dan berpengaruh nyata terhadap loyalitas pelanggan.

\section{Analisis QSPM}

Tahap akhir dalam penentuan urutan alternatif strategi sebagai strategi prioritas yang dilakukan menggunakan alat analisis QSPM berdasarkan pengembangan David (2006). Berdasarkan hasil perhitungan matriks QSPM ayam goreng waralaba, diperoleh strategi yang paling menarik untuk diterapkan adalah menjaga loyalitas konsumen. Adapun urutan strategi prioritas hasil QSPM ayam goreng waralaba adalah:

a. Menjaga loyalitas konsumen dengan mengoptimalkan mutu produk dan pelayanan antara lain cita rasa yang tidak berubah, sikap ramah pada konsumen, mempercepat penyelesaian transaksi (TAS $=0,37$ ).

b. Menjaga brand image (TAS $=0,36$ ).

c. Melakukan promosi melalui penyebaran leaflet, radio lokal dan internet (TAS 0,33 ).

d. Menghadiri dan mengikuti pameran-pameran makanan (TAS $=0,33)$.

Dari analisis QSPM ayam goreng mandiri, diperoleh strategi untuk diterapkan adalah meningkatkan mutu produk dan layanan. Urutan strategi prioritas hasil QSPM ayam goreng mandiri adalah:

a. Meningkatkan mutu produk dan layanan $(\mathrm{TAS}=0,37)$

b. Gencar melakukan pencarian alternatif tambahan modal $($ TAS $=0,34)$.

c. Melakukan promosi sendiri terutama melalui internet, penyebaran leaflet, dan radio lokal $(\mathrm{TAS}=0,33)$.

d. Mempertahankan kesetiaan konsumen dan hubungan baik dengan pemasok (TAS =0,32.

\section{KESIMPULAN}

1. Kelayakan usaha dilihat dari empat kriteria kelayakan analisis keuangan dengan tingkat pengembalian lebih dari bunga deposito 5\%, menunjukkan usaha ayam goreng, baik waralaba maupun mandiri layak dilakukan. Usaha ayam goreng waralaba memberikan tingkat pengembalian hasil lebih cepat 1,10 
tahun dan 15 hari dari pada usaha ayam goreng mandiri.

2. Berdasarkan analisis persepsi konsumen, faktor yang memengaruhi pembelian, baik usaha ayam goreng waralaba maupun usaha ayam goreng mandiri adalah harga, mutu, higienisitas, kepraktisan dan kemudahan diperoleh.

3. Berdasarkan hasil analisis faktor lingkungan, IFE, EFE, IE, SWOT dan QSPM pada masingmasing usaha, didapatkan urutan alternatif strategi untuk usaha ayam goreng waralaba maupun mandiri adalah: (a) Usaha ayam goreng waralaba melakukan penjagaan loyalitas konsumen dengan cara menjaga rasa produk tetap renyah dan bersih, sikap ramah dalam pelayanan, menjaga kebersihan outlet, tidak menaikan harga, menjaga brand image, melakukan promosi melalui penyebaran leaflet, radio lokal dan internet, menghadiri dan mengikuti pameran makanan; dan (b) Usaha ayam goreng mandiri dengan mempertahankan mutu produk dan pelayanan dengan cara membuat rasa produk tidak berubah, melakukan pembelian bahan baku kepada pemasok secara kolektif bersama outlet lain, pencarian alternatif tambahan modal melalui program kemitraan.

\section{DAFTAR PUSTAKA}

Aryanti, D.A. 2010. Kajian Preferensi Konsumen terhadap Beras Berlabel di Wilayah Kecamatan Koja Jakarta Utara [Tesis]. Bogor: Program Pascasarjana, Institut Pertanian Bogor.

Astuti, D. 2005. Kajian Bisnis Franchise Makanan di Indonesia. Jurnal Manajemen \& Kewirausahaan, 7(1): 83-98.
Bridges, E., Briesch. R. A. and Yim, C. K. 2009. Effects of Prior Brand Usage and Promotion on Consumer Promotion Response. Journal of Retailing, 82(4): 295-307

David, F.R. 2006. Strategic Management: Prentice Hall International Inc., New Jersey

Engel, F.J., R.D. Blackwell dan P.W. Miniard. 1994. Perilaku Konsumen (Terjemahan). Binarupa Aksara, Jakarta.

Karamoy, A. 2005. Menjadi Kaya Lewat Waralaba. Pustaka Bisnis Indonesia, Jakarta.

Lee, T.S. and Tsai, H.J. 2005. The Effects of Business Operation Mode on Market Orientation and Innovativeness. Emerald Group Publishing Limited, Industrial Management and Data System, 105(3): 325348.

Nagar, K. 2010. Evaluating the Effects of Consumer Sales on Brand Loyal and Brand Switching segments. VISSION-Journal of Business Perspective, 13(4): 35-48.

Omotayo, O.A. 2011. Sales Promotion and Consumer Loyalty: A Study of Nigerian Financial Industry. Journal of Competitiveness, 3(1): 73-84.

Rivai, M.M. 2012. Pengaturan Waralaba di Indonesia; Perspektif Hukum Bisnis. Jurnal Liquidity, 1(2): 159-166.

Wang, C.M., Tu, Y.T, and Chang, H.C. 2012. Corporate Brand Image and Customer Satisfaction on Loyalty: An Empirical Study of Financial Service in Taiwan. Journal of Social and Development Sciences, 3(1): 24-32.

Wati, Y.D., M. Hubeis dan A. Saleh. 2009. Kajian Program Penyaluran Kredit Usaha Kecil Melalui Program Kemitraan (Kasus PT BNI dengan Lembaga Pendamping IPB). Jurnal MPI, 4(1): 17-37.

Zabidi, Y. 2001. Supply Chain Management : Teknik Terbaru. 